Available online at www.banglajol.info

Bangladesh J. Sci. Ind. Res. 48(4), 247-252, 2013

BCSIR

\section{BANGLADESH JOURNAL OF SCIENTIFIC AND INDUSTRIAL RESEARCH \\ E-mail: bjsir07@gmail.com}

\title{
Pollens in bee-breads as an indicator of honey sources
}

\author{
A. A. Abdulrahaman ${ }^{1 *}$, M. T. Liadi ${ }^{2}$, A. K. Musa, ${ }^{2}$, O. S. Kolawole ${ }^{1}$ and F. A. Oladele ${ }^{1}$ \\ ${ }^{1}$ Department of Plant Biology, Faculty of Science, University of Ilorin, Ilorin, Nigeria \\ ${ }^{2}$ Department of Crop Protection, Faculty of Agriculture, University of Ilorin, Ilorin, Nigeria
}

\begin{abstract}
Adulteration of honey and bee-breads in the markets are becoming a matter of deep corncern. The aim of this study, therefore, is to authenticate the natural sources of the honey and bee breads produced by the University of Ilorin Apiary Farm and Jatropha Plantation. A microscopic survey of some pollen breads collected from the Apiary Farm of 6 colonies and Jatropha Plantation of one colony at the University of Ilorin, Ilorin, Nigeria revealed the presence of 9 types of pollens in honey-breads or bee-breads produced by the bees in the area under study. These pollen types include monoporate, salcate, triporate, tricolpate, pericolpate, panporate, biporate, salcate and vesculate. Monorate, colpate, triporate and panporate pollen types are the most frequent occuring in all colonies, followed by salcate, biporate and tricolpate. The least frequent types are pericolpate and vesculate pollens occuring only in the colony A. Density of each of these pollens were also determined in each colony. Some impurities were detected in colonies B, C and E. Panporate pollen of Jatropha curcas is of high frequency in the colony of Jatropha indicating that honeybees visit the Jatropha plants more frequently. So, the honey from the plantation might contain high percentage of panporate pollens. The honey produced at the Apiary and Jatropha Plantation at the University of Ilorin, Ilorin, Nigeria is based on this study. A polyfloral or multifloral type rather than unifloral or monofloral because it contains many types of pollen indicating its source from more than one plant sources or more than one nectars of different entomophilous plants exhibiting the presence of some anemophilous pollens.
\end{abstract}

Keywords: Bee-bread; Bee; Different kinds of pollens; Honey; Honey source; Melissopalynology; Nectar

\section{Introduction}

Honey is a sweet food made by honey bees (Apis mellifera L.) and other honey producing species using nectar from flowers of entomophilous plants which is drawing attention among people of all walks having its enormous health relevance. It has been prescribed by the doctors as medicine for many ailments of mainkind. Some of these uses include a natural energy booster, treatment of sore throat, sore and burns, as an anticancer, cholestrol fighter, protection against heart diseases, immune system builder etc. Furthermore, honey not only contains monosaccharides that are easily absorbed by the body and it is also better than sucrose in terms of impact on human health. It also contains numerous trace elements, vitamins, minerals and enzymes which take part in human digestive mechanisms.

Besides the popularity of honey there is another essential product obtained from the beehive frequently called beebread (i.e. pollen bread or bee-pollen or ambrosia). Beebread is a compound consisting of pollens that has been packed by the worker honeybees into granules called pollen balls with added honey or nectar. It is subsequently harvested from hives and used as a food supplement by human beings. In other word, bee-pollen may be described as a mixture of bee saliva, plant pollen and nectar. Foraging bees bring pollen back to the hive and pass it off to another worker bee. This bee will pack the pollen into a cell with its head. During packing, the pollen is mixed with nectar, enzymes, fungi and bacteria and organisms that transform the pollen into pollen-bread or bee-bread. The resulting material is higher in nutrition than the untreated pollen. Bee-bread is the primary source of protein for the hive (Sammataro \& Avitabile, 2011). A single bee may carry up to 5 million pollen grains in a single encounter. Some pollens are probably consumed but most pollens are mixed with small quantities of honey or nectar and possibly salivary products and packed into the cells adjacent to the brood nest where it undergoes a chemical change to a product called bee-bread. This product is stored until it is consumed by the adult bees for conversion into a glandular larval food that may be termed as "mother's milk". Bee-bread is the principal food of the adult nurse bees. This nutrient was named by primitive man because of its bready taste. Nurse bees eat and convert bee-bread into at least two different glandular secretions which are again fed to bee larvae.

\footnotetext{
*Corresponding author. e-mail: abdulrahamanaa@unilorin.edu.ng; aaaoacademics@rocketmail.com;
} 
Some people take bee-bread in the belief that it has special health-enhancing properties which acts as an erogenic aid. It has been claimed that bee pollen improves oxygen uptake and helps to accelerate recovery in training. There is no scientific evidence to support claims that bee-pollen improves health or physical performance. Farmers were encouraged to separate out 'bee-bread' from honeycomb during harvesting honey and keeping it for consumption as a 'medicine', especially for children, pregnant woman and lactating mothers, convalescents and the elder ones. On the contrary, it may contain allergy-producing substances that are dangerous to hypersensitive individuals (Wong, 2005).

Fresh pollen stored at room temperature loses its quality within a few days. Fresh pollen stored in a freezer loses much of its nutritive value after one year. Prolonged and improper storage causes losses to particular amino acids, which leads to deficiencies in brood rearing (Dietz, 1975). Pollen can be stored at room temperature for several months. It can be refrigerated at $5^{\circ} \mathrm{C}$ for at least a year or frozen to $15^{\circ} \mathrm{C}$ for many years without any kinds of quality loss as tested by feeding to honeybee colonies and recording brood rearing rate (Dietz \& Stephenson, 1975; Dietz \& Stevenson, 1980). Pollen collected by bees is mixed with nectar and packed into the cells of the honeycomb where ferments slightly to form 'bee-bread'. This contains practically all the essential amino acids, many vitamins (A, B1, B2, B3, B6, C, $\mathrm{E}$ and $\mathrm{H}$, biotin, folic acid and rutin) and minerals (calcium, iron, potassium, phosphorus, sodium). It also has wide range of medicinal applications especially in cases of disturbed metabolism, digestive disorders and allergies (Kaal, 1991).

The current study is, therefore, (1) to determine the flower constant of the honeybees (i.e. to determine frequency of the bees visit to plants), (2) to elucidate the pollen composition of University of Ilorin honey, (3) to ascertain the types of honey and bee-breads produced at the Apiary Farm and Jatropha Plantation i.e. whether it is monofloral or polyfloral, and (4) possibily to determine plant sources of the honey and bee-bread produced at the University of Ilorin, Ilorin, Nigeria.

\section{Materials and methods}

\section{Study Materials}

From seven different colonies, a total of 325 (three hundred and twenty five) pollen-breads were collected (Table I) and designated as colonies A, B, C, D, E, F and colony Jatropha. The pollen breads were preserved in transparent plastics
(Plate 1) and stored in cool environment for subsequent microscopic examinations.

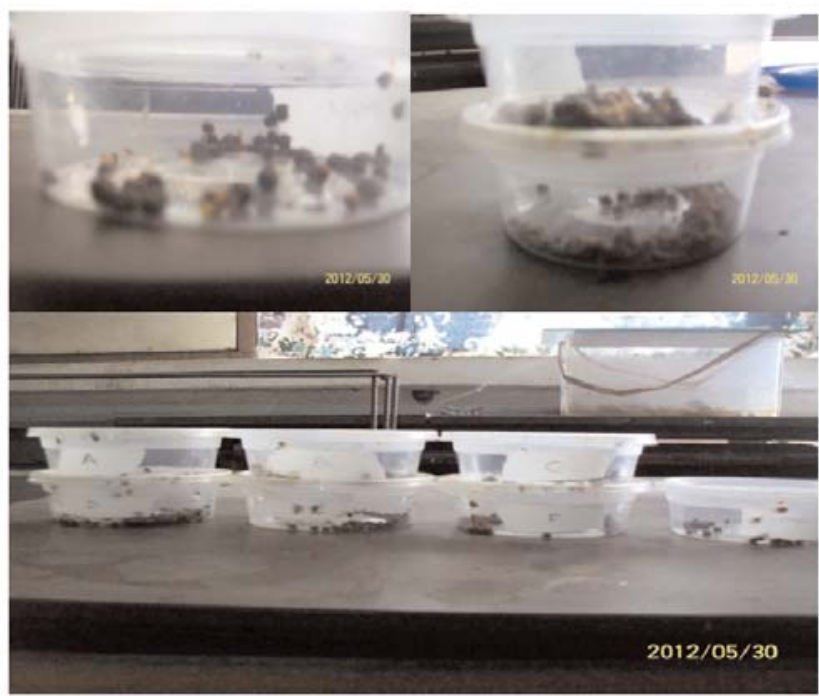

Plate : Pollen-breads collected from seven different colonies in beehives at Apiary Farm and Jatropha Plantation located at the University of Ilorin, Ilorin, Nigeria.

Table I. Location and number of bee-bread collected for analysis from Apiary Farm located at the University of Ilorin, Ilorin, Nigeria

\begin{tabular}{l|c}
\hline Colony & Number of bee-bread collected \\
\hline A & 15 \\
B & 48 \\
C & 50 \\
D & 55 \\
E & 47 \\
F & 66 \\
Jatropha & 44 \\
\hline
\end{tabular}

Study Area

The study area was the Agro Forest Zone of University of Ilorin located in the Guinea Savanna region of Nigeria rich in trees and shrubs with evergreen plants was selected for the study purpose that produces enormous pollens in the wet and dry seasons. Ilorin lies between $8^{\circ} 29^{\prime} 10^{\prime \prime} \mathrm{N}$ and 440'38' E with the elevation of $408 \mathrm{~m}$. The climate of Ilorin is characterized by wet and dry season with annual mean rainfall of about $1150 \mathrm{~mm}$ (Jatto and Ogunlela, 1988). The wet season usually commences around March and ends in October while the dry season is normally from November till February. 
Mean monthly temperature varies from $25^{\circ} \mathrm{C}$ to $29^{\circ} \mathrm{C}$ and the relative humidity varies from $70 \%$ in the dry months to $80 \%$ in the wet months (Akintola, 1986; Jimoh, 1992; Jatto, 1994). The University Agro Forest comprises Jatropha curcas, Citrus species, teak (Tectonia grandis), date palm (Phoenix dactctylifera), moringa (Moringa oleifera) and cashew (Anacardium occidentale) plantations. In spite of the disturbances in the vicinity of the study area, a certain number of animals are present and these include monkeys, hares, grass cutters, giant rats, squirrels, snakes etc. The University has an Apiary Farm with hives and study samples (6 colonies) were collected from this farm including one colony from the Jatropha Plantation.

\section{Microscopic Studies and Pollen Isolation}

Pollen-breads were collected from the nests of the stingless bees and Apis mellifera (common honey-bees) and analyzed to determine the flower constancy of the bees and plant/crops visited by the bees.

Pollen-breads were placed in a small dish. A few drops of isopropyl alcohol (IPA) were added to remove waxy surface of the pollens and it was left for 10 mins. Glycerine jelly was melted (around $40^{\circ} \mathrm{C}$ ) in a water bath. Pollen was mixed with IPA solution, and 2 drops of the liquid mixture were taken. The mixture was placed in one half of the slide and repeated for the other half. One area was stained with glycerine jelly mountant while the other left unstained. IPA was allowed to dry out in $1-2$ mins on a hotplate. The glycerine jelly and cover slip were kept warm. A drop of molten glycerine jelly was placed on a warm coverslip. The upturned slide was lowered slowly so that the pollen grains come in contact with the jelly. By keeping the slide at a slight tilt and lowering slowly, the inclusion of air bubbles was minimized. The slide was removed and placed in a fridge until the jelly become fully set. The cover slip was ringed with nail varnish to create a semi-permanent pollen slide. The slides were mounted with aqueous glycerine. Observations were made with photographs of pollens and tables (Horrock et al., 1999) as amended by Abdul Rahaman et al. 2012. The slide was labelled with the names of the plants or bees and date of pollen collection. The date of the slide preparation was also noted.

\section{Pollen Identification}

Pollens observed in the pollen-breads or bee-breads were identified using some pollen atlas (Bambara and Leidy, 1991; Jones et al., 1995).

\section{Frequency of Pollen Types}

Using 35 snaps of field observation at 40x magnification as quadrat, the number of pores on pollens was noted to determine the frequency of the different pollen types present. Frequency of each pollen type was expressed as percentage occurrence of such pollen type based on all occurrences using the formula given below:

$\mathrm{p} / \mathrm{y} \times 100$

Where,

$p=$ the occurrence of each pollen type in the field of view $\mathrm{y}=$ aggregate occurrence of all pollen types.

\section{Density of Pollen Types}

The density of pollen type was determined as the number of pollen types per square millimetre $\left(\mathrm{mm}^{2}\right)$. Using field snaps taken with 40x objective in each sq. $\mathrm{mm}$ for counting different samples during observation were made.

\section{Results and discussion}

Palynology is an interdisciplinary science and it is a branch of earth science (geology or geological) and biological sciences or particularly plant science (botany). It is the science that studies contemporary and fossil palynomorphs, including pollen, spores, orbicules, dinocysts, arcritarchs, chitinozoans and scolecodonts, together with particulate organic matter (POM) and kerogen found in sedimentary rocks and sediments. Palynomorphs do not include diatoms, foraminferans or other organisms with siliceous or calcareous exoskeletons. Palynomorphs are broadly defined as organicwalled microfossils between 5 and 500 micrometres in size. They are extracted from rocks and sediment cores both physically, by wet sieving, often after ultrasonic treatment, and chemically, by using chemical digestion to remove the nonorganic fraction. Meanwhile, study of pollens in materials such as honey and honey-breads (i.e. melissopalynological or melittopalynological study) revealed the flora source of such materials. Melissopalynology is the study of pollens contained in honey and in particular, the pollen's source. By studying the pollen in a sample of honey, it is possible to gain evidence of the geographical location and genus of the plants that the honey bees visited, although honey may also contain airborne pollens from anemophilous plants, spores, and dust due to attraction by the electrostatic charge of bees.

Generally, melissopalynology is used to combat fraud and inaccurate labelling of honey. Information gained from the study of a given sample of honey (and pollen) is useful when substantiating claims of a particular source for the sample. Monofloral honey derived from one particular source plant 
may be more valuable than honey derived from many types of plants. The price of honey also varies according to the region from which it is collected by the honeybees.

Nine types of pollen were identified from all the seven pollen-breads (Table II; Figs. 1A - 1N) with monoporate, colpate, triporate and panporate been the most frequent occuring in all colonies except in colonies followed by salcate which occurred in six colonies except in Jatropha colony, biporate occur in only three colonies namely colonies $\mathrm{B}, \mathrm{C}$ and $\mathrm{F}$, tricolporate occurred in 3 colony namely $\mathrm{C}, \mathrm{E}$ and $\mathrm{F}$ and the least frequent pollens are porocolpate and vesculate occuring only in colony A. Density of each pollen type which is of significance for each colony (Table II). In some colonies, along with the pollens, some microdebris or impurities were also seen (Fig. 1N). Moreover,

Table II. Types of pollens in the pollen-breads of colonies A - F and Jatropha colony collected from the beehives at the Apiary Farm and Jatropha Plantation of University of Ilorin, Ilorin, Nigeria

\begin{tabular}{ll}
\hline Types of pollen & Description \\
\hline Colpate & Pollen with equatorial deep furrows \\
Salcate & Pollen with distal or pollar furrows \\
Panporate & Pollen with numerous pores \\
Triporate & Pollen with three pores \\
Tricolporate & Pollen with three colpi \\
Monoporate & Pollen with one pore \\
Biporate & Pollen with two pores \\
Pericolpate & Pollen with furrows not meridian \\
Vesculate & Pollen with bladders \\
\hline
\end{tabular}

pollen analysis provides some important information about honey extraction, filtration, and fermentation. Some kinds of adulteration (Kerkvliet et al., 1995) and hygienic aspects such as contamination with mineral dust, soot, or starch grains (Louveaux et al., 1978) have been observed in many honey samples.

Sporollenin a characteristic thick cell wall of pollen that enables it to survive as a fossil is clearly shown in pollen colony marked as B (Fig. 1K). This wall is essential in preservation of pollen for fossil evidence which is applicable in forensic science, exploration of petroleum, exploration of energy and mineral sources as well as ecological information in plants and hay fever (LeRoy, 1977; Ventress, 1991).

Occurrence of monoporate, colpate, triporate and panporate pollens in all the colonies with higher frequency in at least six colonies reflected the higher number of plants producing such pollens in the study areas. These four pollen types are also of higher density in almost all the colonies (Table III). Higher frequency of panporate pollen in the colony of Jatropha where hives are placed at strategic points in the Jatropha Plantation for production of honey tagged asJatropha honey. There were also other pollen types in the colony of Jatropha; the higher frequency of panporate pollens have suggested that the honey produced at the colony of Jatropha might be truly treated as Jatropha honey and this honey is of polyfloral type.

From this study, it is apparent that commercial honey produced at the Apiary Farm may be treated as polyfloral honey as observed in the different pollens obtained from the beebread sources collected from different hives. To ascertain this claim, melissopalynological or melittopalynological (i.e. study of confirmation of pollen component of honey) study

Table III. Frequency and density of pollen types in the pollen- breads of colonies A - F and Jatropha colony harvested from the beehives at the apiary of University of Ilorin, Ilorin, Nigeria

\begin{tabular}{|c|c|c|c|c|c|c|c|c|c|c|c|c|c|c|}
\hline \multirow[b]{2}{*}{$\begin{array}{l}\text { Types of } \\
\text { pollen }\end{array}$} & \multicolumn{7}{|c|}{ Frequency (\%) } & \multicolumn{7}{|c|}{ Density $\left(\mathrm{mm}^{2}\right)$} \\
\hline & $\begin{array}{c}\text { Col } \\
\text { A }\end{array}$ & $\begin{array}{c}\text { Col } \\
\text { B }\end{array}$ & $\begin{array}{c}\text { Col } \\
\text { C }\end{array}$ & $\begin{array}{c}\text { Col } \\
\mathrm{D}\end{array}$ & $\begin{array}{c}\text { Col } \\
\text { E }\end{array}$ & $\begin{array}{c}\text { Col } \\
\mathrm{F}\end{array}$ & $\begin{array}{c}\text { Col } \\
\text { Jat }\end{array}$ & $\begin{array}{c}\text { Col } \\
\text { A }\end{array}$ & $\begin{array}{c}\text { Col } \\
\mathrm{B}\end{array}$ & $\begin{array}{c}\text { Col } \\
\text { C }\end{array}$ & $\begin{array}{c}\text { Col } \\
\text { D }\end{array}$ & $\begin{array}{c}\text { Col } \\
\text { E }\end{array}$ & $\begin{array}{c}\text { Col } \\
\text { F }\end{array}$ & $\begin{array}{l}\text { Col } \\
\text { Jat }\end{array}$ \\
\hline Monoporate & 22.00 & 28.00 & 30.00 & 35.00 & 30.00 & 20.00 & 17.50 & 3.00 & 39.25 & 20.17 & 3.500 & 4.60 & 7.20 & 3.00 \\
\hline Biporate & - & 11.00 & 15.00 & - & - & 5.00 & - & - & 2.25 & 5.50 & - & - & 1.00 & - \\
\hline Colpate & 22.00 & 6.00 & 10.00 & 10.00 & 5.00 & 20.00 & 17.50 & 4.00 & 1.00 & 5.50 & 1.00 & 4.00 & 5.60 & 1.00 \\
\hline Salcate & 8.50 & 11.00 & 10.00 & 10.00 & 10.00 & 20.00 & - & 1.50 & 1.75 & 1.00 & 1.00 & 1.00 & 4.80 & - \\
\hline Panporate & 22.00 & 28.00 & 20.0 & 35.00 & 30.00 & 20.00 & 32.50 & 8.28 & 46.25 & 6.20 & 5.25 & 6.14 & 6.00 & 8.75 \\
\hline Triporate & 16.14 & 16.00 & 10.00 & 10.00 & 10.00 & 5.00 & 32.50 & 1.20 & 4.75 & 1.00 & 1.00 & 16.50 & 6.00 & 10.50 \\
\hline Tricolporate & - & - & 5.00 & - & 15.00 & 10.00 & - & - & - & 1.00 & - & 5.33 & 8.50 & - \\
\hline Pericolpate & 8.50 & - & - & - & - & - & - & 2.50 & - & - & - & - & - & - \\
\hline Vesculate & 1.00 & - & - & - & - & - & - & 0.86 & - & - & - & - & - & - \\
\hline
\end{tabular}

$\mathrm{Col}=$ Colony

Jat = Jatropha Colony 

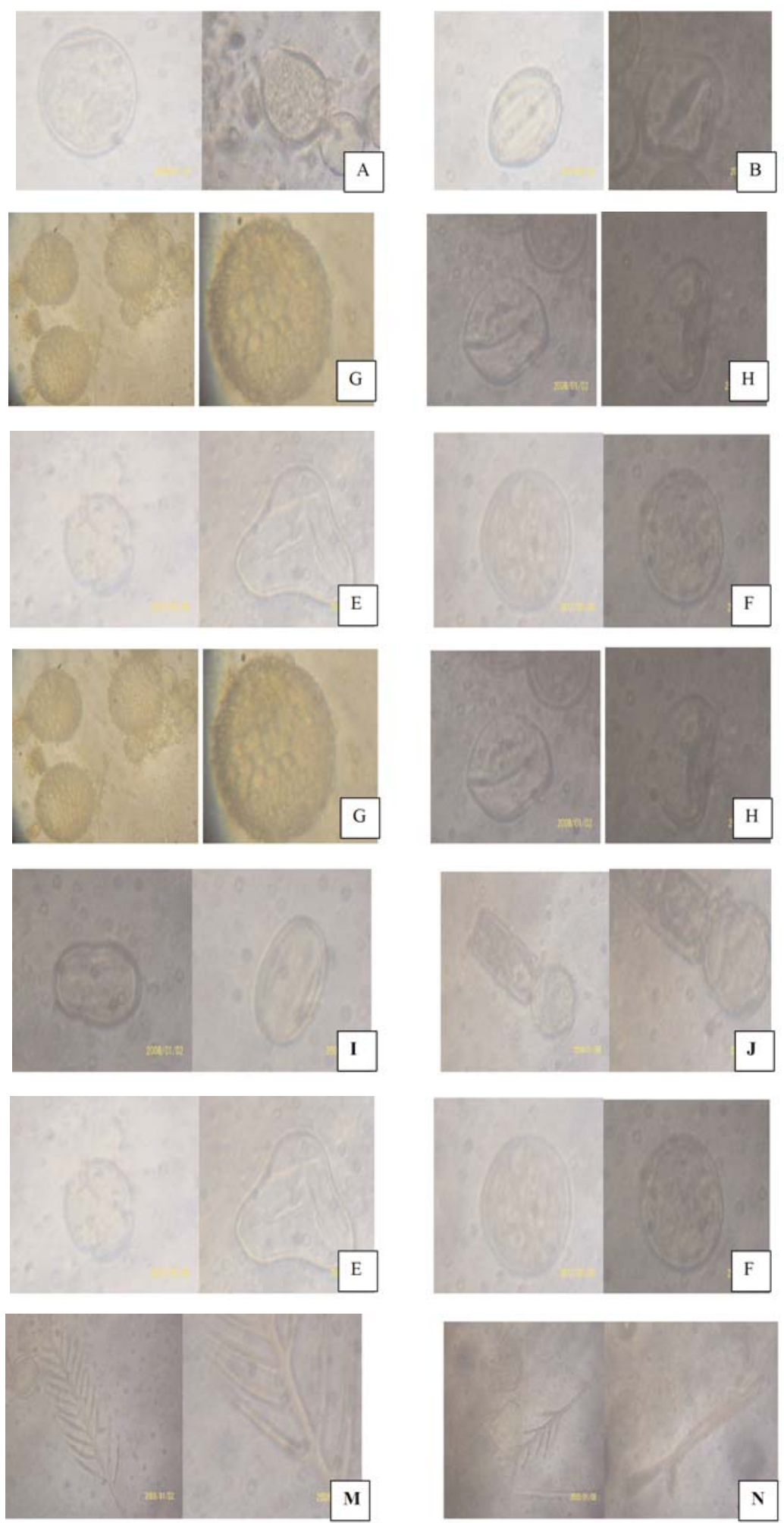

Figs. 1. (A) Monoporate pollen, (B) Colpate pollen, (C) Biporate pollen, (D) Triporate pollen, (E) Tricolpate pollen, (F) Panporate pollen, (G) Panporate pollen of Jatropha curcas, (H) Salcate pollen, (I) Pericolpate pollen, (J) Vesculate pollen, (K) Thick wall sporollenin of pollen in colony B, (L) Impurities in bee-pollens of colony B, (M) Impurities in bee-pollens of colony $C$ and $(N)$ Impurities in bee-pollens of colony $E$ collected from the beehives at the Apiary Farm and Jatropha Plantation of University of Ilorin, Ilorin, Nigeria 
of the honey should be conducted for further studies. Pollen analysis of honey (melissopalynology) is of great importance for quality control. Honey always includes numerous pollen grains (mainly from the plant species foraged by honey-bees) and honeydew elements (like wax tubes, algae and fungal spores) that altogether provide a good fingerprint of the environment where the honey is derived. Pollen analysis can therefore be useful to determine and control the geo graphical and botanical origin of honey even if sensory and physico-chemical analyses are also needed for a correct diagnosis of botanical origin (Ohe et al., 2004).

The possible effects of higher frequency and density of a particular pollen type may include namely (1) the honybee is responsible for high population of the plant family that produced such type of pollen in the study area; (2) which in turn will increase the yield of such plants and (3) subsequent increase in the plant population will definitely increase in the population of the honeybee in return. Therefore, in melissopalynological or melittopalynological study, high frequency and density of a particular pollen denotes the floral source of such honey and reflects the preference of such plant(s) foraged by the bees.

\section{References}

Akintola JO (1986), Rainfall Distribution in Nigeria 1982 1983. Impact Publishers, Ibadan.

Bambara SB and Leidy NA (1991), An atlas of selected pollen important to honey bees in the eastern United States. North Carolina Beekeepers Association, Raleigh.

Dietz A (1975), Nutition of the adult honey bee. In: The Hive and the Honey Bee. Dadant and Sons Inc., Hamilton, I (11):125 - 156 .

Dietz A and Stevenson HR (1980), Influence of long term storage on the nutritional value of frozen pollen for brood rearing of honey bees. Apidologie, 11(2): 143 - 151.

Dietz A and Stephenson SP (1975), The effect of long term storage on the nutritive value of pollen for brood rearing of honey bees. Am. Bee J., 115: 476 - 477.

Horrock M, Coulson SA and Walsh KAJ (1999), Forensic palynology: variation in the pollen content of soil on shoe soles and shoe prints in soil. Journal of Forensic Science, 44(1): 119 - 122.

Jatto BO (1994), Influence of rainfall erosivity parameters effects on soil erosion rates in Ilorin, Nigeria.
Unpublished M. Eng. Thesis. Department of Agricultural Engineering, University of Ilorin, Ilorin, Nigeria.

Jatto SO and Ogunlela AO (1988), Rainfall erosivity parameters effects on soil erosion rates in Ilorin, Nigeria. Centre Point Science Edition, 19(1): 1 - 9.

Jimoh HI (1992), Modeling Sediment Yield from different Land Use Surfaces in Ilorin City, Nigeria. Ph.D. Research Proposal, Department of Geography, University of Ilorin, Ilorin, Nigeria.

Jones GD, Bryant Jr, VM, Lieux MH, Jones SD and Lingren, PD (1995), Pollen of the Southeastern United States: With emphasis on melissopalynology and entomopalynology. American Association of Stratigraphic Palynologists foundation.

Kaal J (1991), Natural medicine from honey bees (apitherapy). Amsterdam: Kaals Printing House. p. 93.

Kerkvliet JD, Shrestha M, Tuladhar K and Manandhar H (1995), Microscopic detection of adulteration of honey with cane sugar and cane sugar products. Apidologie 26: 131-139.

LeRoy DO (1977), Economic Microbiostratigraphy. In L.W. LeRoy, D.O.LeRoy and J.W. Raese. Subsurface Geology - Petroleum - Mining - Construction. Colorado School of Mines. p. 212-233.

Louveaux J, Maurizio A and Vorwohl G (1978), Methods of Melissopalynology. Bee World, 59: 139 - 157.

Ohe WVD, Oddo LP, Piana ML, Morlot M and Martin P (2004), Harmonized methods of melissopalynology. Apidologie, 35: S18 - S25.

Sammataro D and Avitabile A (2011), The Beekeeper's Handbook. Cornell University Press. ISBN 0-80147694-1.

Ventress WPS (1991), Paleontology and its application in South Louisiana Hydrocarbon Exploration, In D. Goldthwaite. (ed.). An Introduction to Central Gulf Coast Geology. New Orleans Geological Society p. 85-97.

Wong C (2005), Bee Pollen. About.com. Retrieved 2009-0120.

Received: 07 April 2013; Revised: 13 November 2013; Accepted: 17 December 2013. 